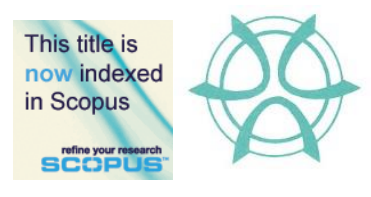

PLANNING MALAYSIA:

Journal of the Malaysian Institute of Planners

VOLUME 15 ISSUE 3 (2017), Page 135 - 146

\title{
TRANSFORMING HERITAGE BUILDING FOR COMMERCIALISATION
}

\author{
Prihatmanti Rani ${ }^{1}$, Cantika Putri ${ }^{2}$, \& Adeline Devina ${ }^{3}$ \\ 1,2,3 Interior Architecture Department \\ CIPUTRA UNIVERSITY, SURABAYA, INDONESIA
}

\begin{abstract}
Adaptive reuse is known as one of the conservation methods to prevent the building from being abandoned, dilapidated, as well as to halt further deterioration of the fabrics, both in interior and exterior. Surabaya has a number of Dutch colonial buildings as evidence of the Dutch settlements for 350 years. The aesthetic value, location and the historical significance of the buildings have made the proprietors conserving those buildings and reusing them as commercial spaces. In this research, two prominent Dutch-colonial mansions have been chosen as the research objects. Those buildings have been transformed into an upscale dining place in Surabaya, Indonesia. Based on the local regulation for heritage building conservation, the designated buildings have adhered to the conservation regulations. However, in some parts, alterations were still discovered and not according to the original of the building. These changes were purposely done in order to accommodate the business owners' need. Therefore, this paper aims to review the transformation of heritage building and the compliance to the regulation.
\end{abstract}

Keyword: Adaptive reuse, heritage building, commercialisation, transformation

Date Received: $1^{\text {st }}$ November 2016

Date of Acceptance: $21^{\text {st }}$ October 2017 
Prihatmanti Rani, Cantika Putri, \& Adeline Devina

Transforming Heritage Building for Commercialisation

\section{INTRODUCTION}

Heritage building is a witness of the past that deserved to be kept to retain the memories. It is also a legacy from the past and should be preserved for our next generation. Besides, the unique building form has distinct characters from the past architectural styles. The aesthetic value embedded in the building has made heritage building interest many people. According to a study by Armitage and Irons (2013), there is a certain pleasure such as a sense of place, belonging or connection that someone could find from the aesthetic quality of heritage buildings. It is widely known from the previous research that physical quality of the building, including the layout, lighting, interior fixture and furnishings, ambience, as well as the air quality are significantly known to affect the customers' emotional response. Therefore, it could create a memorable experience to the customers, provide dining satisfactions as well as their behavioural intentions (Song, 2010; Heung \& Gu, 2012); Chen, Peng \& Hung, 2015). These positive impacts are significantly affecting the patrons' intention to return, spreading positive word-of-mouth, and they are also willingly to pay more (Song, 2010; Chen, Peng \& Hung, 2015).

Thus, there are more and more business owners locate their restaurant in a heritage building in order to capture the patrons' experience in dining. There are five key experience design principles for designing a memorable experience, those are theme the experience, harmonise impressions with positive cues, eliminate negative cues, mix in memorabilia, and engage all the five senses (Pine \& Gilmore, 1999)

This phenomenon also occurred in Surabaya where several heritage buildings are being adaptively reused into restaurants and commercial spaces. However, there are limited discussion among scholars on the transformation of the heritage building, particularly in Surabaya. Previous research studied the ventilation system in tropical-humid architecture (Prianto et al., 2000), the morphological framework of the Chinese and the European districts in Surabaya (Kwanda, 2011), the spatial planning of the Chinese architecture in Surabaya, and the environmental and heritage building conservation on the north of Surabaya (Danardi, Antariksa \& Hariyani, 2010). Therefore, this research focuses on the transformation of the physical aspects of the heritage buildings that have been adaptively reused into commercial spaces.

Surabaya, the second oldest and biggest city in Indonesia, has a number of heritage buildings that have been left by the Dutch during their colonization from the year 1870 until 1940. These buildings currently became evidence of the past memories, a reference, and a legacy for the next generation. The architecture in Surabaya was developed rapidly after the year 1900 when the professional architects came from the Netherland to work in Indonesia including Surabaya. The town planning system, as well as the architectural style created by the Dutch, are still depicted in Surabaya until today. The common architectural style 
PLANNING MALAYSIA

Journal of the Malaysia Institute of Planners (2017)

commonly found in Surabaya is the Empire Style or known as The Dutch Colonial style.

The Dutch Colonial style is influenced by the neo-classical style that occurred in the Europe. however due to the high temperature and heavy rainfall, the buildings that were built in the East Indies, were made to be adaptable to the local climate and using the local materials (Handinoto, 1996). The main building are characterised by symmetrical layout and building mass, 1-2 story building with hip roof, terrace in the front part of the house, Greek-style columns that support the canopy/cantilever as a shade. In terms of the building appearance in accordance with the ventilation system, Colonial Dutch buildings are generally high in ceiling (more than 3.5 meters) and equipped with ventilation mesh, wall full of openings, tall doors and windows, hollowed attic, high roof, path around the buildings as a form of circulation, and a tower that functions as a wind catcher (Prianto et al., 2000)

\section{ADAPTIVE REUSING HERITAGE BUILDING}

UNESCO (1972) has stated that heritage is a legacy and witness from the past of the man-made environment that represents the cultural history and cannot be duplicated or replaced once lost. Moreover, it is also a source of life and inspiration for the next generation. One method for conserving heritage building is by adaptive reusing it. As stated in the Burra Charter, adaptive reuse is rehabilitating or renovating heritage buildings or structures for any uses other than the present uses (Australian ICOMOS, 1999). It involves no change to the culturally significant fabric, changes that are significantly reversible, or changes with minimal impact.

According to Rypkema (2008), there are several positive impacts in adaptive reusing heritage buildings. By adaptive reusing, it could help to reuse the existing public infrastructure. Therefore, it would be cost effective, energy conserving, as well as time saving, compare to constructing new building. Moreover, properly managed and maintained historical buildings could reduce the number of vacant buildings; create viable business districts and employment, as well as could attract visitors.

New uses of adaptive reused heritage buildings are classified into two categories, the active and the passive use. Active use can be defined as a new activity that generates sufficient income to cover restoration and maintenance costs in the adaptive reuse programme, such as hospitality (restaurants, hotels) and commercial (shops and other retails) business. While the passive use does not generate significant income to cover restoration as well as the maintenance cost. However, passive use will bring social benefits to the community such as libraries, museums, welfare housing, etc. (Pimonsathean, 2002)

The Surabaya City government has established the local regulation on heritage building classifications. There are four categories of heritage buildings 
Prihatmanti Rani, Cantika Putri, \& Adeline Devina

Transforming Heritage Building for Commercialisation

in Surabaya.

A. Building that must be maintained its original characters and fabrics where minimum intervention of the conservation methods are required;

B. Building that can be conserved in order to maintain the original characters and fabrics by restoring/rehabilitating or reconstructing;

C. Buildings that are conserved by adaptively reusing it but the building façade must be retained as it was. Alteration is only allowed on the internal parts and must suit the original design of the building;

D. Buildings that are under-utilised and in a risk of demolition. These buildings are legally allowed to be demolished and must be rebuilt as it was.

However, there is a lack of information on the category of the listed heritage buildings in Surabaya. It is compulsory to identify the category of the listed buildings before doing any conservation works.

\section{METHODOLOGY}

To obtain the objective, this research employed a qualitative descriptive method, mainly observation, and interview. This study begins with the literature review on government documents, academic journals, media publication on adaptive reuse of the designated research objects in Surabaya. An observation was conducted to obtain data on the physical aspects of the buildings studied that includes the building fabric, furniture, and furnishings, interior layout, ambience as well as the exterior condition. Interview with the proprietor of each building was also conducted in order to gain deeper data regarding the transformation of functions and form of the buildings. A descriptive analysis was used to describe the differences of the buildings before and after the alteration.

\section{Selection of the Case Study}

The buildings studied were two restaurants of more than 50 years of age, heritage listed buildings, and categorised as B class. According to the heritage regulation and UNESCO (1972), a building can be considered as heritage if it is believed to be more than 50 years of age. The studied buildings are located in the center of Surabaya where the Dutch settlement was located during their occupancy in Surabaya. Those buildings are:

\section{The 1914 Restaurant}

This restaurant is located in the Darmokali 10 street and was built by a Dutch architect named Fritz Joseph Pinedo (assisted by J. van Dongen) in 1913. Previously this building was a resident of a wealthy Chinese descent, Tan Hie Sioe. A few years later, this building was occupied by a Dutch family before it was handed over to the locals (Handinoto, 1996). In 1967, this building was managed by the French Government and converted into a French Cultural Center 
PLANNING MALAYSIA

Journal of the Malaysia Institute of Planners (2017)

(Centre Culturel et de Cooperation Linguistique) as well as the representative office of French Consulate General Surabaya (CCCL Surabaya) until 2012. On the same year, this building was officially gazetted by the Surabaya City government as a heritage listed building. After gazetted, it was then renovated and converted into a high-end restaurant in 2013, named The 1914 Restaurant. This restaurant is a multi-concept destination for food and beverage, entertainment, socialising, as well as for private dining. It offers a variety of Western, Mexican and Asian food, live music lounge, cigar bar, wine cellar and lounge, private function rooms and outdoor garden piazza.

In order to accommodate the concept of this restaurant, this building has undergone several major renovations in some parts of the buildings, both exterior and interior. Since this building is categorised as the B class, any restoration, rehabilitation or reconstruction works are acceptable in order to maintain the original characters of the buildings. The façade of this building is still similar although there are some effects of the alterations can be seen (refer to Fig. 1 and 2).

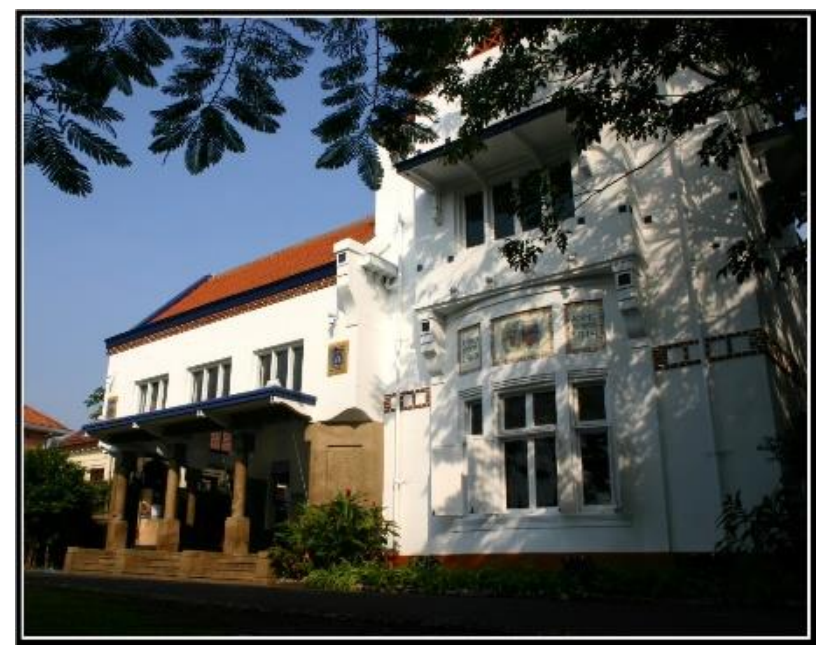

Figure 1 The Façade of CCCL Surabaya

Source: http://rooang.com/wp-content/uploads/2015/06/Gedung-CCCL1.jpg 
Prihatmanti Rani, Cantika Putri, \& Adeline Devina

Transforming Heritage Building for Commercialisation

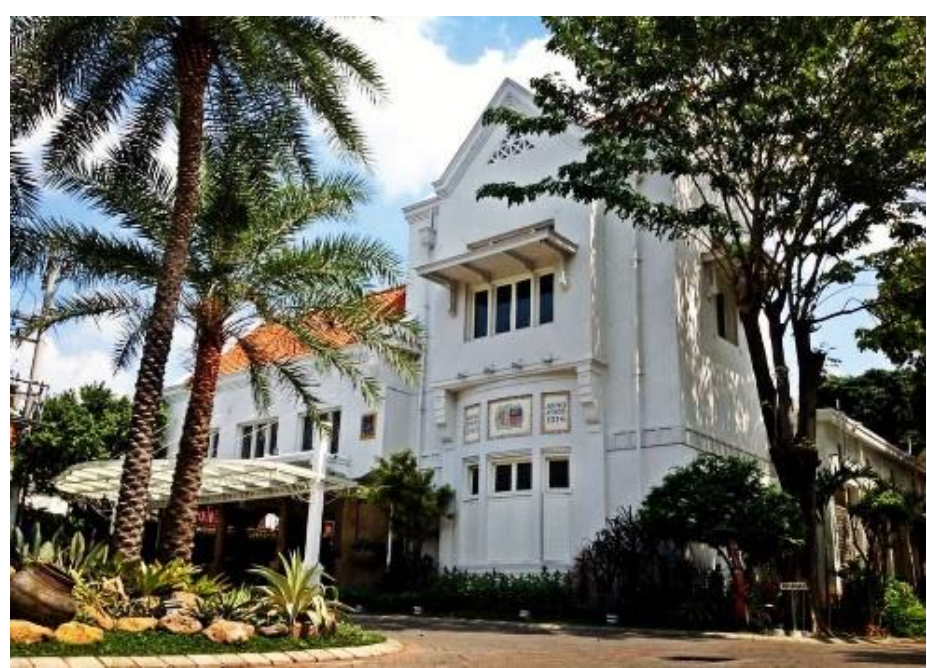

Figure 2 The Current Façade of the 1914 Restaurant Source: https://www.instagram.com/ theconsulatesurabaya/

de Soematra Function House 1910 Surabaya

This building is currently a restaurant housed in an elegantly sumptuous colonial mansion which was built in 1910. In the past, this building was occupied by the AIA Architect Bureau (Algemeen Ingenieurs en Architecten Bureau), a famous architectural and engineering firm during the Dutch period who produced many local landmarks in Surabaya. The location of this building (Sumatera Street/Sumatrastraat No. 75, Surabaya) is known for its luxurious heritage mansions where the Dutch lived. Along this road, there are several upscale restaurants that are occupying the heritage mansions. However, based on the observation, de Soematra is the only building with the least alteration on the architectural elements along this road (see Fig. 3 and 4). After being converted into a restaurant, this place offers five elegantly furnished halls: Indigo Room, Library Room, The Bar Room, The Dining Room, and Function Room with four lounges with a baby piano as Foyer Room, and two lounges. Nevertheless, due to the limitation of the permission in taking photographs, there are only a few images from few areas of the studied building that could be captured for this research. Fig. 3 and 4 show the similarity of the façade, before and after alterations. 
Journal of the Malaysia Institute of Planners (2017)

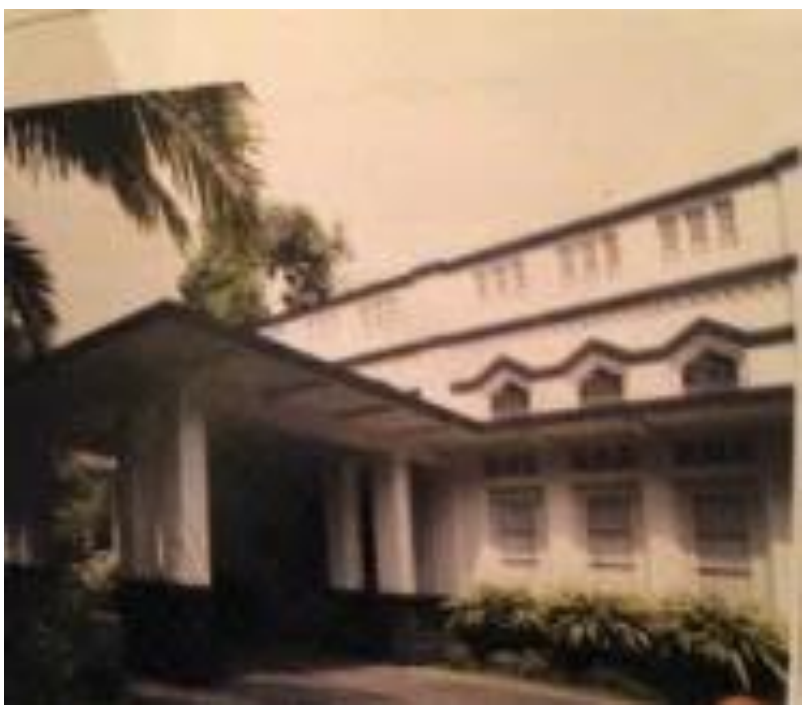

Figure 3 The Building Façade in the Past

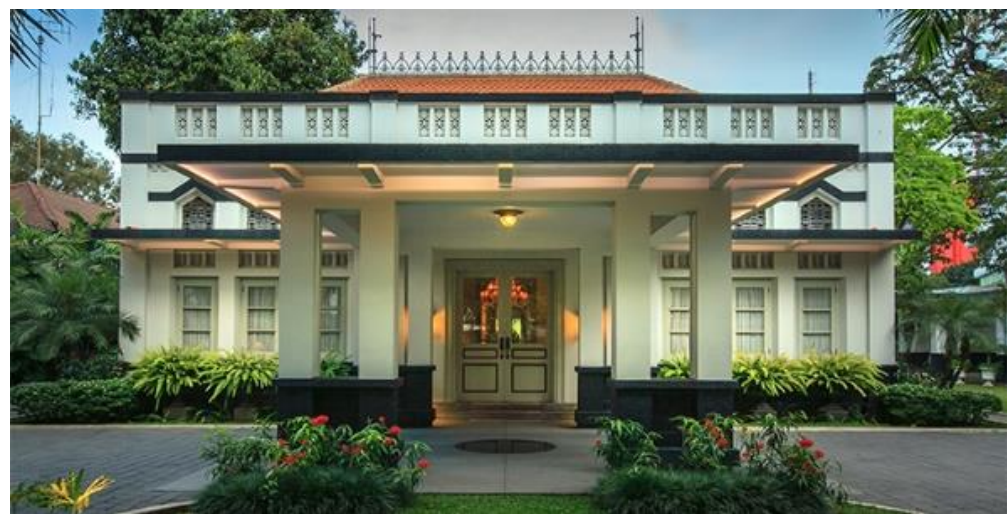

Figure 4 The Current Building Façade Source: http://www.de-soematra.com

\section{RESULTS AND DISCUSSION}

Since this research is focusing on the qualitative data of both buildings, observation, interview and documentation have been conducted during the data collecting period to answer the objective. The result of each building is described and tabulated in Table 1 and 2. A brief conclusion regarding the description of each building was written at the end of each table. 
Prihatmanti Rani, Cantika Putri, \& Adeline Devina

Transforming Heritage Building for Commercialisation

Table 1 The Transformation of The 1914 Restaurant

\begin{tabular}{|c|c|c|}
\hline No. & Current Condition & Observation Result \\
\hline 1. & & $\begin{array}{l}\text { - The landscape and the garden feature are } \\
\text { still maintained as it was. New plants were } \\
\text { added to enhance the aesthetic value. } \\
\text { The form of the garden feature is still the } \\
\text { same, however, the material was replaced } \\
\text { with a different one. Previously it was } \\
\text { made from terracotta; currently, from } \\
\text { stone. }\end{array}$ \\
\hline 2. & & $\begin{array}{l}\text { - The façade is still the same, no significant } \\
\text { alteration. } \\
\text { - The decorative elements on the façade are } \\
\text { well-kept as they were. } \\
\text { - The building facade is painted in white, } \\
\text { typical colonial building colour in } \\
\text { Surabaya. } \\
\text { The stained glass is original and being } \\
\text { carefully maintained. }\end{array}$ \\
\hline 3. & & 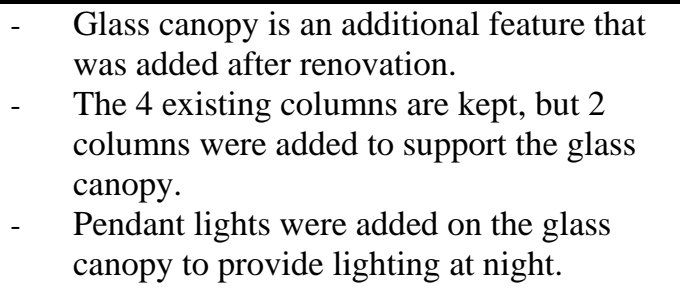 \\
\hline 4. & & $\begin{array}{l}\text { - The ceiling pattern is well-maintained and } \\
\text { still in the original form. } \\
\text { - The chandelier was replaced with the new } \\
\text { design. } \\
\text { - The ceiling pattern on the right image is } \\
\text { still the same as the original building. }\end{array}$ \\
\hline
\end{tabular}


PLANNING MALAYSIA

Journal of the Malaysia Institute of Planners (2017)

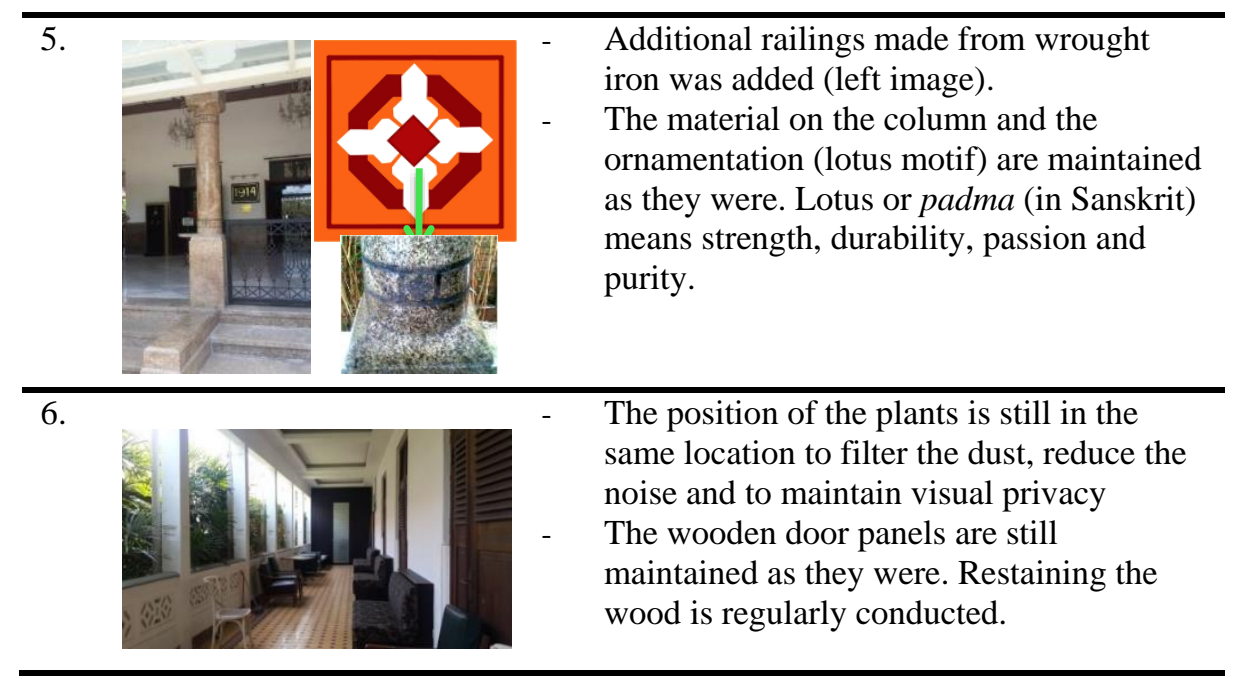

According to the observation result in Table 1, there are changes on the interior and architectural parts of this building. In the main building, the renovation work was fully conducted on the interior of this building. Additional features, such as glass canopy on the façade, were added to provide shelter during rain. Iron railings were also added at the main entrance. Since this building is categorised as the B class heritage building, the façade is maintained on its original characteristics as well as the building fabrics. There are additional building that was built recently in the backyard in order to accommodate the needs based on the business model of this restaurant. The materials and the structure used to renovate this heritage building were not specific for heritage building but only using ordinary building materials. This restaurant, however, does not fully comply the local regulation due to the changes on the whole building. 
Prihatmanti Rani, Cantika Putri, \& Adeline Devina

Transforming Heritage Building for Commercialisation

Table 2 The Transformation of the deSoematra Building

\begin{tabular}{|c|c|}
\hline No. & Current Condition \\
\hline 1. & \\
\hline
\end{tabular}

Observation Result

\begin{tabular}{l} 
- $\begin{array}{l}\text { There are no changes on the building } \\
\text { façade, including the columns, window } \\
\text { panes, door panels, air vents and the roof. } \\
\text { Decorative lightings were added to add } \\
\text { the dramatic ambience of the façade. }\end{array}$ \\
\hline 3. \\
- $\begin{array}{l}\text { The wall is decorated with old pictures of } \\
\text { the building to retain the past memories. } \\
\text { The double swing doors are still } \\
\text { maintained in their original form, only } \\
\text { repainted to suit the overall ambience. }\end{array}$ \\
$\begin{array}{l}\text { The furniture is newly made but the design } \\
\text { and the materials selected were made to } \\
\text { suit the overall heritage yet elegant } \\
\text { ambience. }\end{array}$
\end{tabular}

- The landscape is maintained as it was, but some plants were added to enhance the aesthetic value of this area.

- The garden patio was also included in the original building. ambience. 


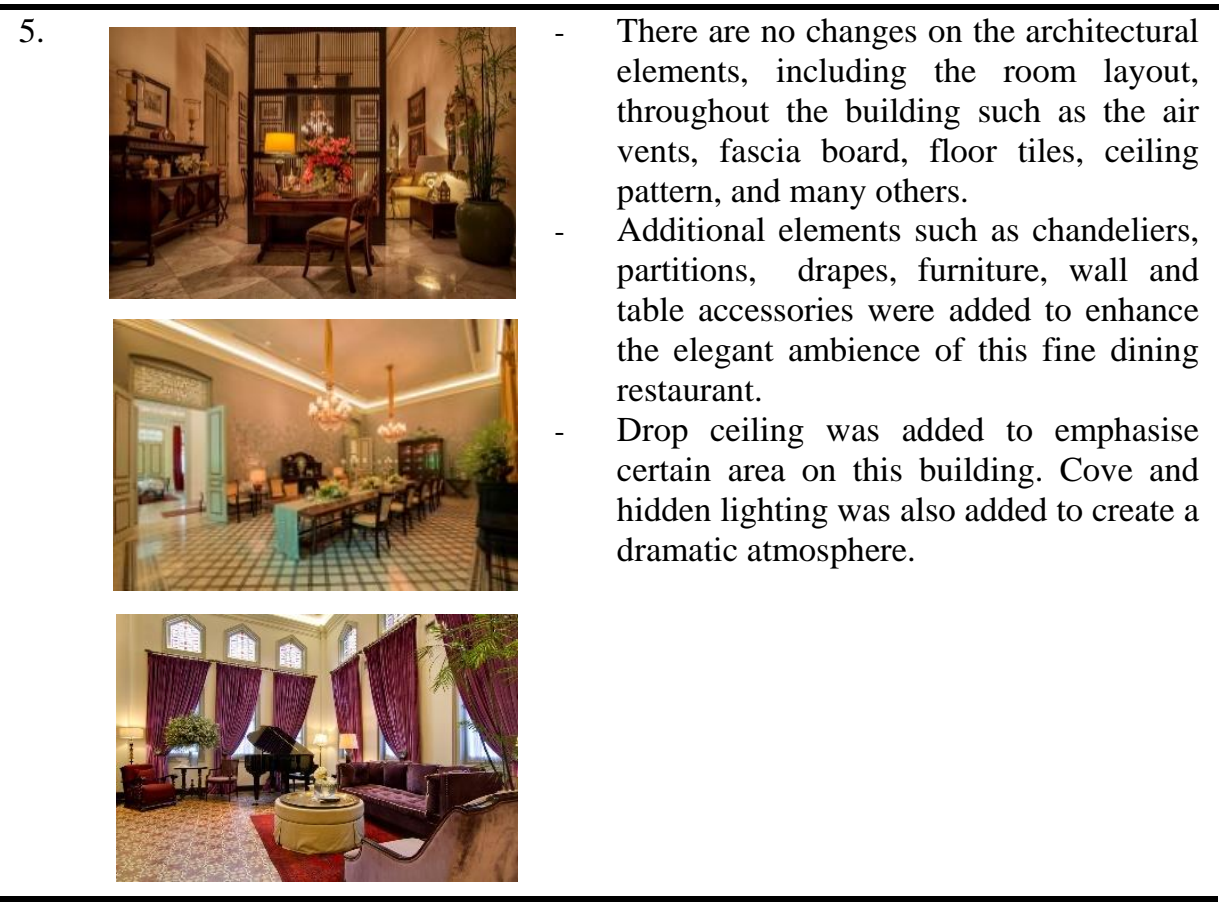

Table 2 shows the studied building already adheres to the principles of conservation as well as the conservation regulation. Despite the changes on the interior, the architectural elements including the layout as well as the façade are still maintained as they were. The conservation work was done according to the original design of the building and maintained regularly until today. The interior design, including the furniture and the embellishments, were well-furnished to perform the elegance of this building. This building is one of the good examples of heritage building conservation in Surabaya.

\section{CONCLUSION}

This research has highlighted the compliance of the heritage building conservation in Surabaya. Two heritage buildings that have been adaptively reused into high-end restaurant were chosen as the research objects. Both buildings were built more than 50 years ago and listed as the national heritage building based on the Surabaya City regulation. According to the regulations, alterations are strictly prohibited on the façade of the buildings to maintain the cultural significance of the building. The local government should be more aware of the heritage listed buildings that are being conserved. They have to ensure that any conservation work must comply with the standards, and are according to the classification of the building. The buildings which are listed must be updated regularly as well as the category of the buildings. The main purpose is to 
Prihatmanti Rani, Cantika Putri, \& Adeline Devina

Transforming Heritage Building for Commercialisation

safeguard heritage buildings and to prevent any conservation work that might jeopardise the heritage value of the buildings.

\section{REFERENCES}

Armitage, L., \& Irons, J. (2013). The values of built heritage. Property Management, 31(3), 246-259. DOI: http://dx.doi.org/10.1108/02637471311321487

Australian ICOMOS (1999). The Burra Charter: The Australia ICOMOS Charter for places of cultural significance (pp. 2-5). Victoria: Australia ICOMOS Incorporated.

Chen, A., Peng, N., \& Hung, K. P. (2015). The effects of luxury restaurant environments on diners' emotions and loyalty. International Journal of Contemporary Hospitality Management, 27(2), 236-260. DOI: http://dx.doi.org/10.1108/IJCHM-07-2013-0280

Danardi, R. W., Antariksa, \& Hariyani, S. (2010). Pelestarian lingkungan dan bangunan kuno di koridor Jalan Rajawali Kota Surabaya. Arsitektur e-Journal, 3(2).

Handinoto (1996). Perkembangan kota dan arsitektur kolonial Belanda di Surabaya 1870-1940. Surabaya: Penerbit Andi.

Heung, V. C. S., \& Gu, T. (2012). Influence of restaurant atmospherics on patron satisfaction and behavioral intentions. International Journal of Hospitality Management, $31(4), \quad 1167-1177 . \quad$ DOI: http://dx.doi.org/10.1016/j.ijhm.2012.02.004

Kwanda, T. (2011). The morphological framework of the Chinese and the European districts in Surabaya, 1787-2005. DIMENSI, 38(1), 1-14.

Pimonsathean, Y. (2002). Current issues concerning adaptive re-use in the conservation of urban cultural heritage. $R C$ : Revista de Cultura $=$ Review of Culture. 4.

Pine, J., \& Gilmore, J. H. (1999). The experience economy. Boston, Harvard Business School Press

Prianto, E., Bonneaud, F., Depecker, P., \& Peneau, J-P. (2000). Tropical-humid architecture in natural ventilation efficient point of view: A reference of traditional architecture in Indonesia. International Journal on Architectural Science, 1(2), 80-95.

Song, J. (2010). Retail design and sensory experience: Design inquiry of complex reality. Proceeding of the International Conference Design and Complexity (pp. 120126). Montreal, Canada: Design Research Society.

UNESCO (1972, November). 7th session at general conference concerning the protection of the world cultural and natural heritage. Paris, France. New York: United Nations. 